\title{
Concise synthesis of truncated pachastrissamine (jaspine B) and its enantiomer
}

\author{
S. Chandrasekhar, ${ }^{*}$ Bhoopendra Tiwari, and S. Jaya Prakash \\ Organic Chemistry Division I, Indian Institute of Chemical Technology, Hyderabad 500007 , \\ India \\ E-mail:srivaric@iict.res.in
}

\begin{abstract}
A short and efficient stereoselective synthesis of truncated pachastrissamine and its enantiomer have been achieved using the Wittig olefination, azidation through imidazole sulfonate ester and one-pot reductive hydrogenation as the key steps.
\end{abstract}

Keywords: Pachastrissamine, Wittig olefination, azidation, imidazole sulfonate ester, one-pot reductive hydrogenation

\section{Introduction}

(+)-Pachastrissamine 1a, a naturally occurring novel anhydrosphingosine derivative, has been isolated recently from the Okanawa marine sponge Pachastrissa sp (family calthropellidae) by Higa and co-workers ${ }^{1}$ and found to posses cytotoxicity at a level of $\mathrm{IC}_{50} 0.01 \mu \mathrm{g} / \mathrm{mL}$ against P388, A549, HT29 and Mell 28 cell lines. Shortly thereafter, the Debitus research group ${ }^{2}$ reported the isolation of the same natural product from a different marine sponge Jaspis $s p$. Pachastrissamine represents the first example of an anhydrosphingosine structural feature in a natural product. In anticancer assays, this novel sphingosine derivative exhibited submicromolar cytotoxic activity against human lung carcinoma cell line using the ATP lite assay. Jaspine B 1a proved to be the most potent compound yet isolated from the Jaspis genus on this cell lines, $c f$. pectenotoxin II $\left(\mathrm{IC}_{50}>10 \mu \mathrm{M}\right),{ }^{3}$ bengamide $\mathrm{Y}\left(\mathrm{IC}_{50}=12.8 \mu \mathrm{M}\right),{ }^{4}$ bengamide $\mathrm{Z}\left(\mathrm{IC}_{50}=10.5\right.$ $\mu \mathrm{M}){ }^{5}$
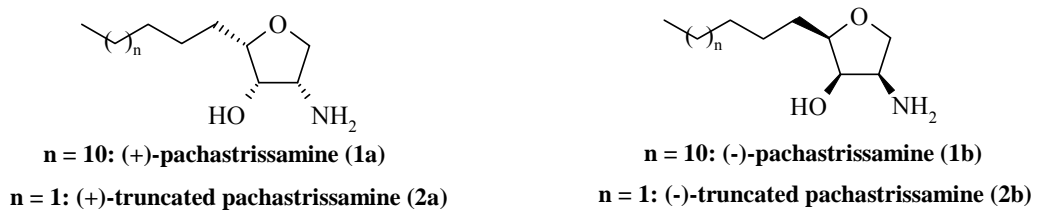
It has been reported that sphingosine 1-phosphate induces a rapid and relevant release of arachidonic acid and increase phospholipase D activity in A549 cells. ${ }^{6}$ The marine sponges even though have provided several bioactive leads, the consistent supply of these compounds has been limited. In order to gain rapid access to these products of biological interests, we have initiated a programme ${ }^{7}$ to synthesise these scarce natural products and their analogues efficiently so that the supply for screening is uninterrupted. Herein we wish to report the concise synthesis of a truncated version of titled compound $\mathbf{2 a}$ and its enantiomer $\mathbf{2 b}$. The same strategy can be also applied for the synthesis of jaspine B with original side chain. The present approach allows one to use various commercially available sugars and design new stereoanalogs with ease. To the best of our knowledge only three syntheses have been reported. ${ }^{8}$

\section{Results and Discussion}

The retrosynthetic analysis depends on the conversion of hydroxyl group at C-2 to sulfuryl imidazylate followed by $\mathrm{S}_{\mathrm{N}}^{2}$ displacement with $\mathrm{N}_{3}$ group in the furanose sugar normally a difficult step owing to its vicinity to anomeric carbon. For (+) and (-) Jaspine (truncated), we began with commercially available L-xylose and D-glucose respectively which were converted to key aldehydes 3a and $\mathbf{3 b}$. Our retrosynthetic approach is outlined in scheme 1.

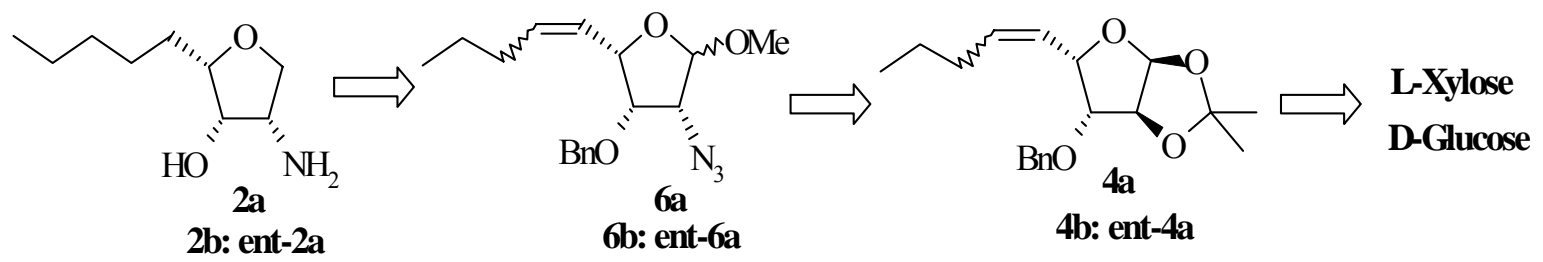

\section{Scheme 1}

The $(+)$ isomer, L-xylose was converted to aldehyde 3a through known sequence of reactions. ${ }^{9} \quad$ The aldehyde $3 \mathbf{a}$ was subjected to Wittig olefination ${ }^{10}$ with n-butyl triphenylphosphonium bromide in THF-HMPA and n-butyl lithium at $-40{ }^{\circ} \mathrm{C}$ to give olefin $4 \mathbf{a}$ with $\mathbf{Z} / \mathbf{E}$ ratio of more than 10:1 in $86 \%$ yield. The hydrolysis of acetonide linkage and in situ formation of the methyl glycoside $5 \mathbf{a}$ was successfully achieved using catalytic $\mathrm{CH}_{3} \mathrm{COCl}$ in methanol. $^{11}$

With the alcohol 5a in hand, we tried several methods e.g. tosylation and mesylation for the $\mathrm{S}_{\mathrm{N}}^{2}$ displacement of hydroxyl group at C-2 with $\mathrm{N}_{3}$ group. But all efforts failed. Even more reactive triflate did not give good yield in nucleophilic substitution and resulted mainly in the elimination product. This problem was circumvented by treating 5a with N, N'sulfuryldiimidazole ${ }^{12}$ and sodium hydride in DMF at $-40{ }^{\circ} \mathrm{C}$ to give imidazole sulfonate ester. Heating this sulfonate ester with $\mathrm{NaN}_{3}$ in DMF gave the desired product 6 a but in poor yield. 
This situation was overcome by using $\mathrm{Bu}_{4} \mathrm{NN}_{3}$ in place of $\mathrm{NaN}_{3}$ giving $6 \mathbf{a}$ in $68 \%$ overall yield for two steps. $\mathrm{Bu}_{4} \mathrm{NN}_{3}{ }^{13}$ was generated by the reaction of tetrabutylammonium chloride and $\mathrm{NaN}_{3}$ as it is not commercially available. (Scheme 2)

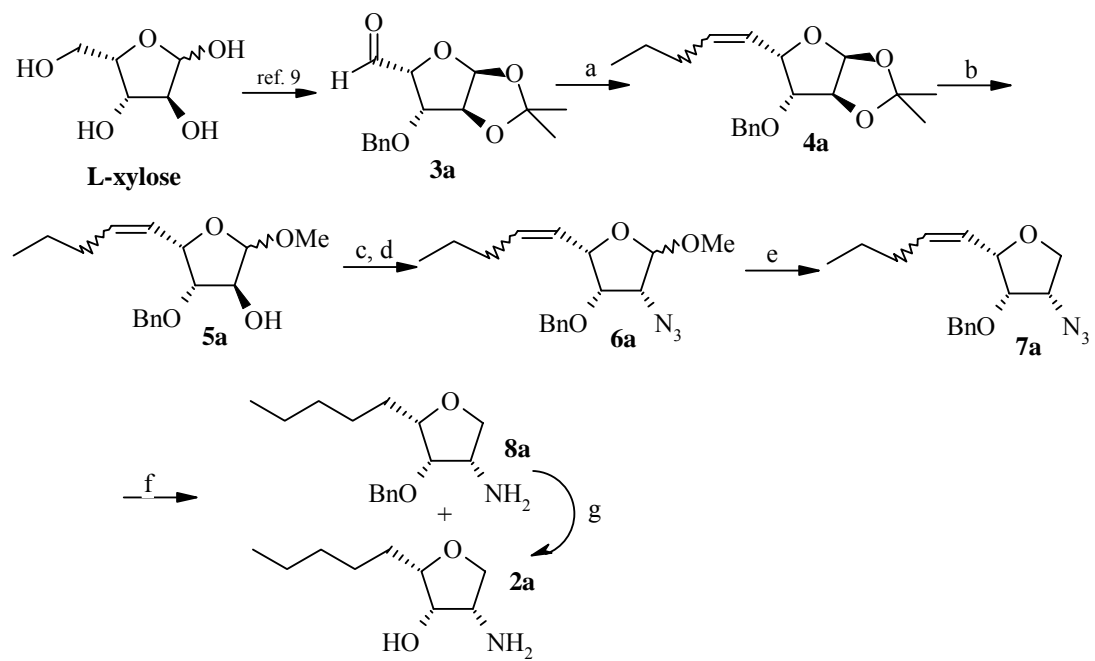

Reagents and conditions: $\mathrm{C}_{4} \mathrm{H}_{9} \mathrm{P}^{+} \mathrm{Ph}_{3} \mathrm{Br}, n$-BuLi, THF-HMPA, $-40{ }^{\circ} \mathrm{C}, 4 \mathrm{~h}, 86 \%$; b) $\mathrm{CH}_{3} \mathrm{COCl}$ (cat), $\mathrm{MeOH}, 60{ }^{\circ} \mathrm{C}, 8 \mathrm{~h}, 95 \%$; c) $\mathrm{SO}_{2} \mathrm{Im}_{2}, \mathrm{NaH}, \mathrm{DMF},-40{ }^{\circ} \mathrm{C}, 3 \mathrm{~h}$; d) $\mathrm{NaN}_{3}, \mathrm{TBACl}, \mathrm{DMF}, 110^{\circ} \mathrm{C}, 12 \mathrm{~h}, 58 \%$ (for two steps); e) $\mathrm{BF}_{3} . \mathrm{OEt}_{2}, \mathrm{Et}_{3} \mathrm{SiH}, \mathrm{CH}_{2} \mathrm{Cl}_{2}, 0{ }^{\circ} \mathrm{C}-\mathrm{rt}, 2 \mathrm{~h}, 94 \%$; f) $\mathrm{Pd} / \mathrm{C}, \mathrm{H}_{2}, \mathrm{MeOH}, \mathrm{rt}, 6 \mathrm{~h}, 70 \%$; g) $\mathrm{Pd} / \mathrm{C}$, $\mathrm{H}_{2}, \mathrm{MeOH}, \mathrm{rt}, 6 \mathrm{~h}$

\section{Scheme 2}

The reductive removal of the methoxy group of $\mathbf{6 a}$ with triethylsilane in the presence of $\mathrm{BF}_{3} . \mathrm{OEt}_{2}{ }^{14}$ proceeded smoothly to give the tetrahydrofuran derivative $7 \mathrm{a}$ in $94 \%$ yield. Finally, reduction of the azide group as well as olefin hydrogenation and cleavage of the benzyl ether was successfully achieved in one-pot. ${ }^{15}$ A mixture of $7 \mathbf{a}$ and $\mathrm{Pd} / \mathrm{C}$ in methanol was stirred under hydrogen atmosphere to furnish the target molecule 2a in good yield along with the formation of a minor product as benzyl ether 8a. The benzyl ether 8a was again subjected to hydrogenation under the same conditions to yield final compound $\mathbf{2 a}$ in complete conversion (scheme 2).

The (-)-enantiomer of truncated pachastrissamine $\mathbf{2 b}$ was also synthesized from D-glucose as a replenishable starting material. Initially $\mathrm{D}$-glucose was transformed to aldehyde derivative 3b employing already known set of reactions. ${ }^{16}$ All above reactions were strategically applied to this aldehyde $\mathbf{3 b}$ to furnish the (-)-enantiomer of truncated pachastrissamine, $\mathbf{2 b}$ in $\mathbf{a}$ stereoselective manner (scheme 3). 


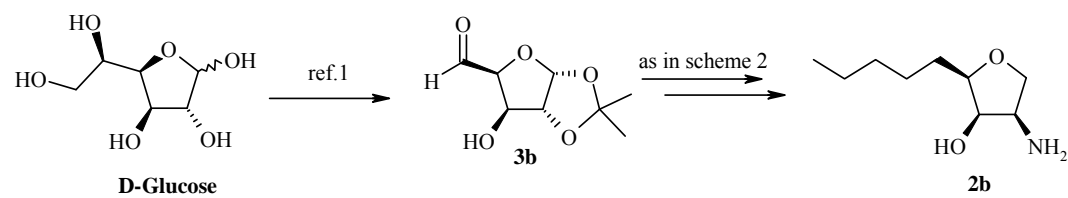

\section{Scheme 3}

\section{Conclusions}

In conclusion, a practical and stereoselective total synthesis of truncated pachastrissamine 2a and its enantiomer 2b has been achieved using Wittig olefination, azidation through imidazole sulfonate ester and one-pot reductive hydrogenation as the key steps. Moreover, this synthetic approach is flexible and can be applied for the synthesis of other analogues with variety of side chain and different stereocentres.

\section{Experimental Section}

General Procedures. Optical rotations were measured with a JASCO DIP-360 Polarimeter at 26 ${ }^{\circ} \mathrm{C}$ and IR spectra were recorded with a Perkin Elmer FTIR spectrophotometer. ${ }^{1} \mathrm{H}$ NMR spectra were carried out using a Varian Gemini 200 or Varian Unity 400 or Bruker Avance $300 \mathrm{MHz}$ spectrophotometer using TMS as an internal standard in $\mathrm{CDCl}_{3}$. Mass spectra were recorded on Micro mass VG-7070H for EI and VG Autospec $\mathrm{M}$ for FABMS mass spectrometers. The progress of all the reactions was monitored by thin-layer chromatography (TLC) using glass plates precoated with silica gel $60 \mathrm{~F}_{254}$ to a thickness of $0.25 \mathrm{~mm}$ (Merck). Column chromatography was conducted by elution of columns with silica gel 60-120 mesh using ethyl acetate and hexane as eluents.

\section{4-Benzyloxy-2,2-dimethyl-5-[1-pentenyl]-(3aS,5S,6R,6aS)-perhydrofuro[2,3-d][1,3]-dioxole} (4a). To a well stirred solution of n-butyl riphenylphosphonium bromide (14.2 g, $35.8 \mathrm{mmol})$ in freshly distilled THF $(50 \mathrm{~mL})$ was added HMPA $(4.18 \mathrm{~g}, 23.3 \mathrm{mmol})$ at room temperature. The mixture was cooled to $-40{ }^{\circ} \mathrm{C}$ and a solution of $\mathrm{n}-\mathrm{BuLi}$ in hexane $(18.7 \mathrm{~mL}, 26.8 \mathrm{mmol}, 1.5 \mathrm{M})$ was added dropwise. The resultant red brick coloured solution was stirred at $-40{ }^{\circ} \mathrm{C}$ for $30 \mathrm{~min}$. A solution of aldehyde $3 \mathbf{a}(5 \mathrm{~g}, 17.9 \mathrm{mmol})$ in THF was added slowly over a period of $20 \mathrm{~min}$ at $-40{ }^{\circ} \mathrm{C}$. The reaction mixture was further stirred for a period of 1 hour at $-40{ }^{\circ} \mathrm{C}$ and then allowed to warm up to room temperature. The reaction mixture was quenched with saturated $\mathrm{NH}_{4} \mathrm{Cl}$ solution and extracted with ethyl acetate $(3 \mathrm{X} 60 \mathrm{~mL})$. The combined extract was washed with water, brine, dried over $\mathrm{Na}_{2} \mathrm{SO}_{4}$ and concentrated. The residue was purified by column chromatography to yield 4a $\left(4.9 \mathrm{~g}, 86 \%\right.$ ) as colourless oil: $[\alpha]_{\mathrm{D}}{ }^{25}+77.33$ (c 2.6, $\left.\mathrm{CHCl}_{3}\right),{ }^{1} \mathrm{H}$ NMR (200 MHz, $\left.\mathrm{CDCl}_{3}\right) ; \delta$ 7.32-7.23 (m, 5H), $5.88(\mathrm{~d}, 1 \mathrm{H}, J=3.2 \mathrm{~Hz}), 5.68-5.62(\mathrm{~m}, 2 \mathrm{H})$, 
4.90-4.84 (m, 1H), 4.62-4.55 (m, 3H), $3.74(\mathrm{~d}, 1 \mathrm{H}, J=3.2 \mathrm{~Hz}), 2.17-1.98(\mathrm{~m}, 2 \mathrm{H}), 1.33-1.27(\mathrm{~m}$, $8 \mathrm{H}), 0.91(\mathrm{t}, 3 \mathrm{H}, J=7.2 \mathrm{~Hz}) ;{ }^{13} \mathrm{C} \mathrm{NMR}\left(50 \mathrm{MHz}, \mathrm{CDCl}_{3}\right): \delta 135.04,128.33,127.7,127.4,123.5$, $111.3,104.6,83.3,83.0,75.8,72.0,30.0,26.8,26.2,22.5,13.7 ; \quad$ IR (neat) $\mathrm{cm}^{-1} 3415,2960$, 2933, 2871, 1617, 1376, 1076, 1025; MS (ESI): $m / z 315(\mathrm{M}+\mathrm{Na})^{+}{ }^{+} 243,201,150$; $\mathrm{HRMS}$ : Calcd for $\mathrm{C}_{19} \mathrm{H}_{26} \mathrm{O}_{4} \mathrm{Na}(\mathrm{M}+\mathrm{Na})^{+}: 341.1728$ Found 341.1713

4-Benzyloxy-2-methoxy-5-[1-pentenyl]-(3S,4R,5S)-tetrahydro-3-furanol (5a). A catalytic amount of $\mathrm{CH}_{3} \mathrm{COCl}$ was added to a solution of $4 \mathbf{a}(4 \mathrm{~g}, 12.4 \mathrm{mmol})$ in methanol $(20 \mathrm{~mL})$. The reaction mixture was refluxed for overnight and then solvent was removed in vacuo. The residue was dissolved in EtOAc $(50 \mathrm{~mL})$ and washed with saturated aqueous $\mathrm{NaHCO}_{3}$, brine, dried with $\mathrm{Na}_{2} \mathrm{SO}_{4}$ and concentrated. The organic residue was purified by column chromatography to give both anomers of $5 \mathrm{a}(3.5 \mathrm{~g}, 95 \%)$ in $1: 1$ ratio. $[\alpha]_{\mathrm{D}}{ }^{25}-41.36\left(\mathrm{c} 2.45, \mathrm{CHCl}_{3}\right)$; ${ }^{1} \mathrm{H}$ NMR $(300$ $\left.\mathrm{MHz}, \mathrm{CDCl}_{3}\right) ; \delta 7.32$ - $7.22(\mathrm{~m}, 5 \mathrm{H}), 5.69-5.59(\mathrm{~m}, 2 \mathrm{H}), 4.95(\mathrm{~d}, 1 \mathrm{H}, J=4.5 \mathrm{~Hz}), 4.88(\mathrm{q}, 1 \mathrm{H}, J$ $=5.2 \mathrm{~Hz}), 4.58(\mathrm{q}, 2 \mathrm{H}, J=12.0 \mathrm{~Hz}), 4.24-4.18(\mathrm{~m}, 1 \mathrm{H}), 3.80(\mathrm{q}, 1 \mathrm{H}, J=3.0 \mathrm{~Hz}), 3.49(\mathrm{~s}, 3 \mathrm{H})$, $2.66(\mathrm{~d}, 1 \mathrm{H}, J=6.0), 2.15-2.01(\mathrm{~m}, 2 \mathrm{H}), 1.48-1.35(\mathrm{~m}, 2 \mathrm{H}), 0.92(\mathrm{t}, 2 \mathrm{H}, J=7.5 \mathrm{~Hz}) ;{ }^{13} \mathrm{C} \mathrm{NMR}$ $\left(75 \mathrm{MHz}, \mathrm{CDCl}_{3}\right): \delta$ 138.0, 134.8, 128.2, 127. 5,127.5, 124.8, 101.7, 84.8, 77.2, 74.1, 71.8, 55.6, 29.8, 22.6, 13.6; IR (neat) $\mathrm{cm}^{-1} 3416,2931,1617,1113,1040 ; \mathrm{MS}(\mathrm{ESI}): \mathrm{m} / z 315(\mathrm{M}+\mathrm{Na})^{+}$, $243,201,150$

3-Azido-4-benzyloxy-2-methoxy-5-[1-penyenyl]-(3R,4S,5S)-tetrahydro furan (6a). To a well stirred suspension of freshly activated $\mathrm{NaH}(0.51 \mathrm{~g}, 12.9 \mathrm{mmol}, 60 \% \mathrm{w} / \mathrm{v}$ dispersion in mineral oil) in anhydrous DCM (5mL), a solution of alcohol 5a $(2.5 \mathrm{~g}, 8.6 \mathrm{mmol})$ in dry DCM was added dropwise at $0{ }^{\circ} \mathrm{C}$ and stirred for $30 \mathrm{~min}$ at room temperature. The reaction mixture was cooled to $-40{ }^{\circ} \mathrm{C}$ and to this added a solution of sulfuryl diimidazole $(2.5 \mathrm{~g}, 12.9 \mathrm{mmol})$ in dry DCM $(5$ $\mathrm{mL}$ ) at $-40{ }^{\circ} \mathrm{C}$ and stirred for one hour at this temperature. To this added $0.01 \mathrm{~mL}$ of methanol at $-40{ }^{\circ} \mathrm{C}$ and further stirred for $30 \mathrm{~min}$ at $-40{ }^{\circ} \mathrm{C}$. The reaction mixture was allowed to warm up to $0{ }^{\circ} \mathrm{C}$ and quenched with ice. The aqueous layer was extracted with DCM $(3 \mathrm{X} 20 \mathrm{~mL})$. The combined organic extract was washed with water, brine, dried over $\mathrm{Na}_{2} \mathrm{SO}_{4}$ and concentrated. To the solution of this crude product in dry DMF was added $\mathrm{NaN}_{3}(0.046 \mathrm{~g}, 7.1 \mathrm{mmol})$ and tetrabutylammonium chloride $(1.9 \mathrm{~g}, 7.1 \mathrm{mmol})$ and stirred for overnight at $110{ }^{\circ} \mathrm{C}$. The reaction mixture was diluted with water and the aqueous layer extracted with ether $(3 \mathrm{X} 20 \mathrm{~mL})$. The combined organic layer was washed with water, brine, dried over $\mathrm{Na}_{2} \mathrm{SO}_{4}$ and concentrated. The crude product was purified by column chromatography to give 6a $(0.71 \mathrm{~g}, 58 \%$ for both steps $)$ as colourless oil. $[\alpha]_{D}{ }^{25}-2.7\left(c 1.10, \mathrm{CHCl}_{3}\right){ }^{1} \mathrm{H} \mathrm{NMR}\left(200 \mathrm{MHz}, \mathrm{CDCl}_{3}\right) \delta 7.34-7.24(\mathrm{~m}$, $5 \mathrm{H}), 5.70-5.64(\mathrm{~m}, 2 \mathrm{H}), 4.94-4.82(\mathrm{~m}, 2 \mathrm{H}), 4.58(\mathrm{q}, 2 \mathrm{H}, J=11.8 \mathrm{~Hz}), 4.19(\mathrm{t}, 1 \mathrm{H} J=5.9 \mathrm{~Hz})$, $3.74-3.68(\mathrm{~m}, 1 \mathrm{H}), 3.37(\mathrm{~s}, 3 \mathrm{H}), 2.16-2.01(\mathrm{~m}, 2 \mathrm{H}), 1.49-1.36(\mathrm{~m}, 2 \mathrm{H}), 9.28(\mathrm{t}, 3 \mathrm{H}, J=7.4$ $\mathrm{Hz}) ;{ }^{13} \mathrm{C} \mathrm{NMR}\left(50 \mathrm{MHz}, \mathrm{CDCl}_{3}\right): \delta 137.2,135.0,128.2,127.7,127.6,124.7,105.6,79.8,74.7$, 73.3, 66.4, 55.4, 29.7, 22.6, 13.6; IR (neat) $\mathrm{cm}^{-1} 2929,2107,1737,1455,1265,1102,1045$; MS (ESI): $318(\mathrm{M}+\mathrm{H})^{+}, 283$, 255; HRMS Calcd for $\mathrm{C}_{17} \mathrm{H}_{23} \mathrm{~N}_{3} \mathrm{O}_{3} \mathrm{Na}(\mathrm{M}+\mathrm{Na})^{+} 340.1637$ Found : 340.1647 .

4-Azido-2-[1-pentenyl]-(2S,3S,4S)-tetrahydro-3-furanyl benzyl ether (7a). A catalytic amount of $\mathrm{BF}_{3} . \mathrm{OEt}_{2}$ was added to a solution of $\mathbf{6 a}(0.13 \mathrm{~g}, 0.42 \mathrm{mmol})$ in anhydrous DCM $(5 \mathrm{~mL})$ 
at $0{ }^{\circ} \mathrm{C}$ and stirred for $15 \mathrm{~min}$ at the same temperature. To this added triethylsilane $(0.15 \mathrm{~g}, 1.26$ $\mathrm{mmol}$ ) at $0{ }^{\circ} \mathrm{C}$ and further stirred for $2 \mathrm{~h}$ at room temperature. The reaction mixture was diluted with water and aqueous layer was extracted with DCM $(3 \mathrm{X} 15 \mathrm{~mL})$. The combined organic extract was washed with water, brine, dried over $\mathrm{Na}_{2} \mathrm{SO}_{4}$ and concentrated. The crude product was purified by column chromatography to afford $7 \mathbf{a}(0.11 \mathrm{~g}, 94 \%)$ as colourless oil. $[\alpha]_{\mathrm{D}}{ }^{25}+$ 83.1 (c 1.45, $\left.\mathrm{CHCl}_{3}\right) ;{ }^{1} \mathrm{H}$ NMR $\left(200 \mathrm{MHz}, \mathrm{CDCl}_{3}\right) ; \delta$ 7.35-7.29 (m, 5H), 5.71-5.63 (m, 2H), 4.72-4.57 (m, 3H), $4.05(\mathrm{t}, 1 \mathrm{H}, J=5.2 \mathrm{~Hz}), 3.95-3.80(\mathrm{~m}, 3 \mathrm{H}), 2.17-1.95(\mathrm{~m}, 2 \mathrm{H}), 1.51-1.32(\mathrm{~m}$, 2H), $0.92(\mathrm{t}, 3 \mathrm{H}, J=7.2 \mathrm{~Hz}) ;{ }^{13} \mathrm{C}$ NMR $\left(75 \mathrm{MHz}, \mathrm{CDCl}_{3}\right): \delta 137.4,134.7,128.3,127.8,127.7$, 125.2, 80.4, 75.9, 73.7, 68.6, 61.6, 29.7, 22.6, 13.6; IR (neat) $\mathrm{cm}^{-1} 2959,2871,2103,1454,1267$, 1121, 1060, 982; MS (ESI): $m / z$ 305.1 $\left(\mathrm{M}+\mathrm{NH}_{4}\right)^{+}, 310.1(\mathrm{M}+\mathrm{Na})^{+}$; HRMS: Calcd. for $\mathrm{C}_{16} \mathrm{H}_{21} \mathrm{~N}_{3} \mathrm{O}_{2} \mathrm{Na}(\mathrm{M}+\mathrm{Na})^{+}: 310.1531$, Found: 310.1541 .

Jaspine B (2a). A mixture of 7a $(0.11 \mathrm{~g}, 0.3 \mathrm{mmol})$ and $10 \% \mathrm{Pd}-\mathrm{C}(0.05 \mathrm{~g})$ in methanol $(5 \mathrm{~mL})$ was stirred for overnight at room temperature under $\mathrm{H}_{2}$ atmosphere (3atm). The catalyst was filtered off and filtrate concentrated in vacuo to give a residue which was purified by column chromatography to give 2a $(0.06 \mathrm{~g})$ in $92 \%$ yield as a yellowish oil; $[\alpha]_{\mathrm{D}}{ }^{25}+55.7(c 0.45$, $\left.\mathrm{CHCl}_{3}\right) ;{ }^{1} \mathrm{H}$ NMR $\left(300 \mathrm{MHz}, \mathrm{CDCl}_{3}\right) ; \delta 3.95-3.85(\mathrm{~m}, 2 \mathrm{H}), 3.76-3.61(\mathrm{~m}, 2 \mathrm{H}), 3.56-3.48(\mathrm{~m}$, $1 \mathrm{H}), 2.01-1.89$ (bs, 3H), $1.73-1.60(\mathrm{~m}, 2 \mathrm{H}), 1.44-1.25(\mathrm{~m}, 6 \mathrm{H}), 0.89(\mathrm{t}, 3 \mathrm{H}, J=6.7 \mathrm{~Hz}) ;{ }^{13} \mathrm{C}$ NMR $\left(75 \mathrm{MHz}, \mathrm{CDCl}_{3}\right): \delta 83.1,70.1,69.8,58.3,31.9,29.6,25.8,22.5,14.0$; IR (neat) $\mathrm{cm}^{-1}$ 3485, 3414, 1618, 618; MS (ESI): $m / z 174(\mathrm{M}+\mathrm{H}),{ }^{+} 102(\mathrm{M}-71),{ }^{+}$HRMS: Calcd for $\mathrm{C}_{9} \mathrm{H}_{20} \mathrm{NO}_{2}$ $(\mathrm{M}+\mathrm{H})^{+}:$174.1494, Found: 174.1495 .

NOTE: For all the intermediates arising from D-glucose reaction procedure, physical properties and spectral datas are same corresponding to L- xylose intermediates except specific rotation with opposite sign.

\section{Acknowledgements}

BT and SJP thank Council of Scientific \& Industrial Research, New Delhi for research fellowships. We also thank Department of Science and Technology for financial support.

\section{References and Footnotes}

IICT communication no. 060306

1. Kuroda, I.; Musman, M.; Ohtani, I. I.; Ichiba, T.; Tanaka, J.; Gravalos, D. G.; Higa, T. J. Nat. Prod. 2002, 65, 1505.

2. Ledroit, V.; Debitus, C.; Lavaud, C.; Massiot, G. Tetrahedron Lett. 2003, 44, 225.

3. O'Connel, P. W.; Tsien, S. H. Arch. Biochem. Biophys. 1959, 80, 289. 
4. ApSimon, J. W.; Hannaford, A. J.; Whalley, W. B. The Chemistry of Fungi; The School of Pharmacy: London, 1965; Vol. XLIX, pp 4164-4168.

5. Sugiyama, S.; Honda, M.; Komori, T. Liebigs Ann. Chem. 1988, 619.

6. (a) Vasta, V.; Meacci, E.; Catarzi, S.; Donati, C.; Farnararo, M.; Bruini, P. Biochim. Biophys. Acta. 2000, 1483, 154. (b) Meacci, E.; Vasta, V.; Moorman, J. P.; Bobak, D. A.; Bruini, P.; Moss, J. ; Vaughan, M. J. Biol. 1999, 274, 18605.

7. (a) Chandrasekhar, S.; Jagadeshwar, V.; Prakash, S. J. Tetrahedron Lett. 2005, 46, 3127. (b) Chandrasekhar, S.; Prakash, S. J.; Shyamsunder, T. Tetrahedron Lett. 2005, 46, 6651. (c) Chandrasekhar, S.; Chandrashekar, G. Tetrahedron Asymmetry 2005, 16, 2209 (d) Chandrasekhar, S.; Narsihmulu, C.; Sultana, S. S.; Reddy, M. S. Tetrahedron Lett. 2004, 45, 9299.

8. (a) Sudhakar, N.; Kumar, A. R.; Prabhakar, A.; Jagadeesh, B.; Rao, B. V. Tetrahedron Lett. 2005, 46, 325. (b) Bhaket, P.; Morris, K.; Stauffer, C. S.; Datta, A. Org. Lett. 2005, 7, 875. (c) Du, Y.; Liu, J.; Linhardt, R. J. J. Org. Chem. 2006, 71, 1251.

9. (a) Bordier, A.; Compain, P.; Mrtin, O. R.; Ikeda, K.; Asano, N. Tetrahedron Asymmetry 2003, 14, 47. (b) Renaud, P.; Millet, J.; Sepulchre, C.; Theveniaux, J.; Barberousse, V.; Jeanneret, V.; Vogel, P. Helv. Chim Acta 1998, 81, 2043. (c) Streicher, H.; Meisch, J.; Bohner, C. Tetrahedron 2001, 57, 8851.

10. Yadav, J. S.; Mishra, R. K. Tetrahedron Lett. 2002, 43, 1739.

11. Chandrasekhar, S.; Ramachandar, T.; Rao, B. V. Tetrahedron Asymmetry 2001, 12, 2315.

12. Hanessian, S.; Batele, J. M. Tetrahedron Lett. 1981, 22, 3579.

13. (a) Davis, S.; Mallerron, A.; Dini, C.; Carbohydr.Res. 1989, 188, 193. (b) Hashimoto, H.; Araki, K.; Saito, Y.; Kawa, M.; Yoshimura,Y.; Bull. Chem Soc. Jpn. 1986, 59, 3131. (c) Alais, J.; Davis, S. Carbohydr. Res. 1992, 79, 230.

14. Bruckner, C.; Hiltrud, H.; Reissig, H.-U. J. Org. Chem. 1988, 53, 2450.

15. (a) Koviach, J. L.; Chappell, M. D.; Halcomb, R. L J. Org. Chem. 2001, 66, 2318. (b) Cossy, J.; Willis, C.; Bellosta, V.; BouzBouz, S. J. Org. Chem. 2002, 67, 1982. (c) Chandrasekhar, M.; Chandra, K. L.; Singh, V. K. Tetrahedron Lett. 2002, 43, 2773. (d) Stauffer, C. S.; Datta, A. Tetrahedron Lett. 2005, 46, 6469.

16. (a) Lubineau, A.; Gavard, O.; Alais, J.; Bonnaffe, D. Tetrahedron Lett. 2000, 41, 307. (b) Arun, M.; Joshi, S. N.; Puranic, V. G.; Bhawal, B. M.; Deshmukh, A. R. A. S. Tetrahedron 2003, 59, 2309. (c) Wolfrom, M. L.; Hanessian, S. A. J. Org. Chem. 1962, 27, 1800.

17. (a) Lubineau, A.; Gavard, O.; Alais, J.; Bonnaffe, D. Tetrahedron Lett. 2000, 41, 307. (b) Arun, M.; Joshi, S. N.; Puranic, V. G.; Bhawal, B. M.; Deshmukh, A. R. A. S. Tetrahedron 2003, 59, 2309. (c) Wolfrom, M. L.; Hanessian, S. A. J. Org. Chem. 1962, 27, 1800. 